University of Warwick institutional repository

This paper is made available online in accordance with

publisher policies. Please scroll down to view the document

itself. Please refer to the repository record for this item and our

policy information available from the repository home page for

further information.

To see the final version of this paper please visit the publisher's website. Access to the published version may require a subscription.

Author(s): Watson M.; Hay C.

Article Title: The Discourse of Globalisation and the Logic of No

Alternative: Rendering the Contingent Necessary in the Political

Economy of New Labour', Policy and Politics

Year of publication: 2003

Link to published version:

http://dx.doi.org/10.1332/030557303322034956

Publisher statement: This is a post-peer-review, pre-copy edited version of an article published in Policy \& Politics. The definitive publisher-authenticated version Watson, M. et al. (2003). Policy \& Politics. The Discourse of Globalisation and the Logic of No Alternative: Rendering the Contingent Necessary in the Political Economy of New Labour', Policy and Politics, pp. 289-305 is available online at: http://dx.doi.org/10.1332/030557303322034956. 


\title{
The Discourse of Globalisation and the Logic of No Alternative: Rendering the Contingent Necessary in the Political Economy of New Labour
}

\author{
Matthew Watson and Colin Hay
}

Published in Policy and Politics, 30 (4), 2004, 289-305.

\begin{abstract}
Although widely and convincingly discredited in academic circles, the crude 'business school' globalisation thesis of a single world market continues to dominate the political discourse of globalisation, as does the political 'logic of no alternative' that it is seen to conjure. The British Labour Party was an early convert to such a thesis, forging its votemaximising economic policy for the 1997 General Election within a discursive context bounded by the assumption of globalisation. After re-election in 2001, the Party continued to defend such an assumption. In this article, we seek to move beyond simple empirical rejections of the 'business school' globalisation thesis. Instead, we focus explicitly on the discourse of globalisation. Firstly, we argue that there are three separate, albeit reinforcing, articulations of the policy 'necessities' associated with global economic change - each grounded in a different intellectual tradition. In other words, globalisation's 'logic of no alternative' is, in fact, a flexible synthesis of three distinct political-economic logics. Secondly, we scrutinise the narratives of globalisation upon which the Labour Party's governance strategy was publicly predicated, tracing the implications for the conduct of economic policy in Britain since 1997. We show that Labour's leaders utilised precisely such a flexible synthesis of (often mutually incompatible) ideas in constructing its political discourse of globalisation. We conclude that the Party appealed to the image of globalisation as a non-negotiable external economic constraint in order to render contingent policy choices 'necessary' in the interests of electoral rejuvenation.
\end{abstract}

\section{Key Words}

globalisation, discourse, ideas, political economy, New Labour 


\section{Introduction}

Globalisation has increasingly come to be seen as a non-negotiable external economic constraint, circumscribing the parameters of both political possibility and political choice. ${ }^{*}$ Although rarely specified in any detail, we take globalisation at minimum to imply processes/tendencies that are either genuinely global in scope or genuinely trans-national in content. This conception of globalisation has had a particular purchase in Britain, coming to be associated in particular with New Labour. As we seek to demonstrate in this paper, globalisation became an active ingredient of British political discourse through a series of high-profile speeches delivered by Labour leaders between 1995 and 1997. Challenged to outline the Party's economic policy prior to the 1997 General Election, Tony Blair and Gordon Brown responded with a series of statements that marked a significant departure from previous policy. This strategic reorientation was clearly set within the context of a discourse of globalisation. Moreover, this was a specific discourse of globalisation, which served to reinforce the normative political stance which the Party's leaders had by this time come to embrace. In this way, the distinction between the 'inevitable' and the 'desirable' was subtly and, we suggest, strategically blurred in order to increase the potency of the message being relayed.

That message was a simple one. The political practices and ideologies that served to sustain the 'embedded liberalism' of the post-war period were no longer feasible nor desirable. The new structural 'reality' was one of increasingly disembedded market exchange, the conditioning effects of which served merely to affirm the wisdom of the Party's prior ideological shift, its ongoing political reorientation and, indeed, more recently, its promotion of itself as a model of a 'renewed' social democracy for European export (see, for instance, Clift 2001; Lovecy 2001).

\footnotetext{
* The authors would like to acknowledge funding and support from the ESRC for their research on 'Globalisation, European Integration and the European Social Model' (Grant No.: L213252043). Earlier versions of the paper have been presented at conferences in Baltimore, Birmingham, Boston (MA), Cambridge (MA) and Keele. We are extremely grateful to participants, panelists and discussants on each occasion for encouraging and perceptive comments. In particular, we would like to thank Sheri Berman, Mark Blyth, David Coates, Philip G. Cerny, Catherine Fieschi, Peter Hall, Richard Higgott, Ben Rosamond, Vivien Schmidt, Daniel Wincott and Brigitte Young.
} 
In this article, we cast a rather different perspective on this highly significant moment in the political economy of British and, potentially, European capitalism. We investigate the way in which a specific set of understandings of globalisation came to dominate Labour's thinking in the years immediately prior to its election, tracing the implications for its tenure to date in office. We argue that a particular political discourse of globalisation, rather than the transformation of the international economy that such a discourse purported to represent, summoned the 'inevitable' political effects now inscribed at the heart of Labour's economic policy. ${ }^{1}$ Our analysis has a dual focus. We begin by reviewing a number of rather different intellectual routes that lead to a conception of globalisation consistent with that espoused by Labour's leaders at this time. We then assess the narrative of globalisation that has consistently underpinned Labour's economic stance since the mid 1990s, concentrating in particular on the ideas around which that narrative was constructed. We conclude, firstly, that Labour's globalisation discourse was predicated upon a contingent, and politically expedient, combination of elements drawn from a range of different intellectual traditions; and, secondly, that although contradictory, these traditions converged on a common political discourse of globalisation as a non-negotiable external economic constraint. We suggest that whilst for Labour, the invocation of globalisation as an exogenous economic constraint served to render the otherwise contingent necessary, an examination of the discursive means by which this was achieved suggests the need to render that which has come to be seen as necessary once again contingent.

\footnotetext{
${ }^{1}$ And now re-inscribed at the heart of Labour's economic policy for the second term. See Brown (2001).
} 


\section{Rendering the contingent necessary: three routes to the political 'logic' of economic compulsion}

[T]he explanation [of globalisation] itself has become a political force helping to create the institutional realities it purportedly merely describes (Piven 1995: 108).

The suggestion of early globalisation scholars that recent processes of structural economic change imply an inexorable process of neo-liberal convergence has now been widely discredited (see for instance, Berger and Dore 1996; Boyer and Drache 1996; Kleinknecht and ter Wengel 1998; Hirst and Thompson 1999). It may, then, seem somewhat indulgent to begin an analysis of globalising tendencies by once again revisiting such arguments. Morbid curiosity aside, there is an obvious reason for so doing. For, in theoretical and, perhaps more importantly, empirical terms, the crude 'business school' globalisation thesis has been exposed for the myth that it undoubtedly is. Yet, in terms of political rhetoric, it continues to exert a powerful influence.

The familiarity of such conventional ideas about globalisation stems from the frequency with which they are rehearsed by those whose interventions are accepted as both legitimate and authoritative. As Paul Krugman perceptively notes,

Endless rounds of meetings [and] speeches ... occupy much of the time of the economic opinion leaders. Such interlocking social groupings tend at any given time to converge on a conventional wisdom, about economics among other things. People believe certain stories because everybody important believes them. Indeed, when a conventional wisdom is at its fullest strength, one's agreement with that conventional wisdom becomes almost a litmus test of one's suitability to be taken seriously (Krugman 1995).

This is nowhere more evident, we contend, than with respect to the conventional economic wisdom now associated with the term globalisation. However, what follows should not be understood as a description of a universal condition. Our concern is merely to demonstrate, and to trace the implications of, the significant shift in British economic discourse in recent years. Within the confines of such an analysis, it is clear that the image of non-negotiable exogenous economic imperatives 
was harnessed strategically in order to displace responsibility for otherwise unpalatable social and economic reforms, arguably pursued for entirely different ends. The justification of reform trajectories (particularly those associated with the scalingback of social provision as reflected in the tightening of eligibility criteria) in terms of the appeal to external economic imperatives (whether globalisation or European Monetary Union) is now an established feature of contemporary European political discourse. Unremarkably perhaps, it is most closely associated with governments of the centre-left who find themselves unable, for whatever reasons, to halt an established process of welfare retrenchment. Of course, whilst in aggregate terms welfare expenditure (as expressed as a proportion of GDP) has continued to rise in most OECD economies, once we control for demand-inflationary pressures (such as demographic change, increased unemployment and escalating health care costs) there is unambiguous evidence of systematic welfare retrenchment (Hay 2001a). Such a process is likely to proceed at different speeds and to take different forms in different countries. This suggests the value of a comparative analysis (such as Hay and Rosamond 2002). Here, however, we restrict ourselves to a more detailed analysis of a particularly early and enthusiastic convert to such a strategy, the British Labour Party.

\section{Route One: The Business School Globalisation Thesis}

The constant repetition of the invariably 'harsh' economic realities of new times has served to embed a particular reading of post-war British economic history. That history effectively divides the post-war period in two. Prior to the crisis of the 1970s, the relative closure of the advanced industrial economies made possible interventionist and expansionary macroeconomic policies and even dirigiste industrial strategies. $^{2}$ Thereafter, with the advent of a technologically-induced globalisation process, formerly independent economies have been integrated into a single global structure. Within such an environment, anything other than the strictest

\footnotetext{
2 This is, of course, not to suggest that all governments exploited such opportunities at all times; only that the prevailing structure of the international economy was seen to facilitate active political control of this nature.
} 
macroeconomic orthodoxy is no longer feasible. Any government caught contemplating a return to the days of autonomous expansionary policies is inviting retribution upon itself at the hands of international financial investors.

Such were the claims of the still highly influential 'business school' globalisation literature (see, for instance, Reich 1992; Barnet and Cavanagh 1994; Sachs and Warner 1995) and the no less significant literature which sought to translate its parsimonious generalisations into policy precepts (see, for instance Giddens 1998, 2000, 2001; Gray 1997, 1998). Both identified on-going processes of exogenous economic change which were rapidly transferring power from 'the state' to 'the market'. In the world so depicted, were governments, by whatever perverse logic, still attracted by the prospects of a unilaterally expansionary macroeconomic stance, the integration of financial markets would ensure a rapid haemorrhaging of invested funds. The influence of such a view is not difficult to demonstrate, as the International Monetary Fund's report on the 'opportunities and challenges' presented by globalisation attests well. “International financial markets ... serve to 'discipline’ governments ... encouraging the adoption of appropriate policies, and ultimately rewarding good policies” (IMF 1997: 66). Currency speculators and hedge fund managers may well have replaced Adam Smith's 'butcher, brewer and baker' as the agents of the 'invisible hand'. But the very fact that the former are far less constrained by time and space than their predecessors in this role has served to bestow on the 'invisible hand' a genuinely global compass. However, the logic, albeit intensified, is essentially preserved. The obvious casualty in this are those aspects of the social contract — such as the welfare state and the commitment to full employment - traditionally seen as national in character and design. Each of these must now be trimmed or sacrificed in accordance with the overriding imperative of economic competitiveness in an increasingly 'borderless' world (Cerny 1990, 1997; Gray 1997; Ohmae 1990). Globalisation, thus understood, announces the global diffusion of the strictest macroeconomic orthodoxy; there is simply no alternative.

During the mid 1990s, this view was rapidly established as the public face of the globalisation thesis in Britain. It was reflected in the editorial columns, financial and business pages of the tabloid and broadsheet media alike. Its conclusion - the identification of a logic of political 'necessity' which undermined the progressive 
values of a welfare society — was simple; and the business school globalisation thesis was perhaps the simplest route to that conclusion — route one.

It was not, however, the only one. We now move from analytical assumptions which originate in the business studies literature to those whose roots are in political economy. Here particularly significant was the 'modified structural dependence thesis’ (Przeworski and Wallerstein 1988; Wickham-Jones 1995).

\section{Route Two: The Structural Dependence Thesis}

That thesis is a simple one. It concerns the state's supposed structural dependence upon capital and, in particular, the consequences of heightened capital mobility (in an era of globalisation) for this relationship. As Adam Przeworski and Michael Wallerstein note, "politicians seeking re-election must anticipate the impact of their policies on the decisions of firms because these decisions affect employment, inflation, and the personal income of voters: vote-seeking politicians are dependent on owners of capital because voters are” (1988: 12). The state is thus dependent upon capital in the sense that its very continuity as a political entity is reliant upon the ability to secure conditions conducive to further investment and capital accumulation. In an era of enhanced exit options, capital mobility and potential flight, this places considerable constraints on the political latitude of parties vying for state power. For, if we can assume that capital is likely to associate the election of a social democratic administration with higher levels of domestic taxation and, in an integrated global economy, enjoys near perfect mobility, ${ }^{3}$ then the merest hint of the election of a social democratic government is likely to be accompanied by a rapid and destabilising exodus of capital. This means that social democratic parties, and even parties such as Labour whose social democratic associations have always been somewhat ambiguous, must effectively abandon their remaining social democratic credentials to accommodate themselves to the perceived interests of capital. If they fail to accept

\footnotetext{
${ }^{3}$ It should be noted at this stage that, however unrealistic such assumptions, they are essential to the model.
} 
political demands for low taxation, labour market flexibility (through deregulation), ${ }^{4}$ welfare retrenchment and fiscal austerity, the very suggestion of their election is likely to precipitate disinvestment, currency speculation and subsequent economic crisis. Once again, within the parameters of such a thesis, there is simply no alternative to the strictest macroeconomic orthodoxy within contemporary capitalism. Routes one and two converge.

What is so remarkable about such a thesis is the extent to which it would seem to encapsulate Labour's strategic assessment of the context it projected for itself prior to 1997 and, indeed, finds itself in today. Put another way, its behaviour - then and now - would appear entirely consistent with that of a utility-maximising social democratic party were the structural dependence thesis valid. That strategy has been to distance itself quite explicitly from social democratic policies each and every time it has been made aware of the potential mobility of capital. This, as Mark WickhamJones has made clear in a series of careful and important analyses, can be seen in its studious courting, since 1992, first of domestic industry, then the City of London and, eventually, international investors from Wall Street to Singapore (1995, 1996, 2000). With each realisation that feasible disinvestment strategies were available to capital, Labour's leaders have reoriented party policy towards the interests of the next most mobile fraction of capital. Even the destinations to which its leaders have flown to outline the Party's understanding of the constraints associated with globalisation would seem to exhibit a logic consistent with the structural dependence thesis. The details of Labour's early economic modernisation were directed principally to domestic audiences. Yet, as the constraints of globalisation were acknowledged, the target audience was similarly globalised, the venue for the targeting of the audience ever further from Britain's shores. The message implicit in this needs little deciphering. Whilst the domestic electorate was to be convinced that it had nothing to fear from Labour's economic policy in the early modernisation era, the same sentiments were to be addressed to overseas investors as Labour came to internalise the discipline implied by the 'material reality' of globalisation.

\footnotetext{
${ }^{4}$ It is important to emphasise that there are other routes to labour-market flexibility than deregulation.
} 
Of course, the fact that Labour can be argued to have acted as if the 'modified structural dependence thesis' were true is not in any sense confirmation of such a thesis (see Hay 1997). What it does suggest, however, is the need to interrogate the assumptions on which the economic logic of structural dependence is premised if we are to understand the political logic of no alternative that Labour has increasingly come to embrace.

Such logics radiate outwards from a particular conception of the process of disinvestment and the socially disembedded exchange relations that such a process implies. In order to comprehend the intellectual roots of this distinctive conception of exchange relations, it is necessary to move from political economy to economic theory.

Route Three: The Need for Counter-Inflationary Credibility

As is now widely acknowledged, the attempt to render mainstream economic theory more 'scientific' has led to formal abstractions which overlook the social and institutional context within which economic relations are necessarily embedded (see, for instance, Hodgson 1988; Jessop 1990: O’Neill 1998). Accordingly, the assumption of frictionless markets tends to be accepted in orthodox economic theory as both entirely conventional and similarly uncontentious. What is most important about this for current purposes is that such an assumption is the direct and functional equivalent of the open economy assumption in the business school globalisation literature (Watson 2001). What in one account is delivered by the assumption of perfect factor mobility is, in the other, delivered by the failure to acknowledge theoretically the different institutional domains within and between which economic transactions occur.

Like that of perfect factor mobility, the assumption of frictionless markets is, at best, crude and simplistic — as indeed it must be if it is not to exclude the possibility of the parsimonious and predictive model-building that is the raison d'être of the analytical 
perspectives which adopt it. ${ }^{5}$ At worst, it is demonstrably false. However, the true significance of the assumption of frictionless markets lies not in its perceived realism (most economists would concede that it is false), so much as the perceived legitimacy of the policy-making prescriptions which are founded upon it.

Much of the presumed logic of political constraint that Labour derived from globalisation can be traced to the association drawn between heightened capital mobility and the increased salience of 'commitment', 'credibility' and 'reputation' (although, see Watson 2002). ${ }^{6}$ Since the mid-1970s, the general thrust of macroeconomic theory has concentrated on the presumed inflationary bias which results when monetary policy decisions are controlled by elected officials. Due to underlying electoral imperatives, governments are assumed to exhibit 'timeinconsistent' inflation preferences. ${ }^{7}$ Typically, in the run-up to elections, they will trade inflation for lower levels of unemployment. Such trade-offs, it is argued, are inefficient, serving in the long-term only to compound extant inflationary dynamics (McKnabb and McKenna 1990). This diagnosis places great emphasis upon counterinflationary credibility and the (largely institutional) means by which this might be secured. Governments that lack such a reputation need not follow a lax inflationary policy to trigger destabilising outward flows of capital. All that is required is for the owners of mobile assets to believe that, some time in the future, the government will renounce its current counter-inflationary policy, for them to seek to invest their assets elsewhere. Crucial, then, is the ability to construct suitable enforcement mechanisms (such an independent central banks mandated to deliver price stability) that will precommit those responsible for monetary policy to a tough counter-inflationary stance (see Persson and Tabellini 1990).

The image of a single global capital market capable of 'policing' government unemployment preferences in line with credible counter-inflationary commitments featured prominently in Labour’s chosen account of exogenous economic constraint.

\footnotetext{
${ }^{5}$ Of course, the business school globalisation thesis shuns precisely the formal modelling which serves to render such simplistic assumptions necessary in the first place.

${ }^{6}$ For an excellent review of the literature, see Drazen 2000.

7 On the seminal articulation of the 'time-consistency' dilemma, see Kydland and Prescott (1977); for a rather different understanding of the same issue, see Taylor (1983).
} 
Globalisation, it argued, ruled out all alternatives to a strictly orthodox economic policy (Balls 1998; and, for a commentary Watson 1999a). If the business school globalisation thesis might be seen as route one, the structural dependence thesis route two, then this is route three. The convergence is again clear. Yet where the three accounts do differ is in their specification of the mechanism by which globalisation's political logic of no alternative is imposed, with the emphasis here placed on the need to institutionalise rigid inflation targets.

This warrants further unpacking. In an era of global financial relations, the state's structural dependence on capital is most acute in the financial sector - the arena within which an economy's inflation performance is largely determined. As Geoffrey Garrett notes, "the easier it is for asset holders to move their capital offshore, the stronger the incentives for governments to pursue policies that will increase rates of return on domestic investment” (1995: 667). In such a world, credible counterinflationary commitments can be assumed to lessen the external constraints on government policy in so far as they safeguard returns on domestic investment. It is the establishment and maintenance of anti-inflationary credibility that is arguably the core precept of New Labour’s political economy (see also Coates and Hay 2001).

As the above paragraphs suggest, we are confronted with three separate, if mutually reinforcing, articulations of the policy 'necessities' associated with global economic change. In the remaining sections of this article, we aim to show that Labour invested a considerable amount of energy prior to its election in constructing a strategic discourse of globalisation capable of securing a lasting place in the public consciousness. The underlying rationale for such a discourse is relatively straightforward - to enforce the impression that, like it or not, Labour found itself in a potentially hostile policy environment defined, as it was circumscribed, by a set of non-negotiable economic constraints. This was presented as the new 'structural reality' to whose imperatives all realistic contenders for government had to conform. Arguably, in practice, it committed an aspirant centre-left administration to the policy set to which it had, by this stage, already committed itself.

In the following section, we challenge the view that this strategic discourse of globalisation was merely a description of an underlying 'structural condition'. We 
demonstrate that Labour's globalisation discourse drew upon a contingent and eclectic combination of elements drawn from a range of different - and often incommensurate — intellectual traditions. We find evidence that Labour's leaders used elements of each of the three political-economic logics outlined above in order to construct an overarching logic of political 'necessity' where the economic 'realities' themselves did not warrant one. Three themes will be evident in our survey of Labour's globalisation discourse:

1. Labour appealed to precisely the type of power transfer from 'state' to 'market' found in the business school globalisation thesis;

2. It appealed to the necessary internalisation of the interests of capital suggested by structural dependence theorists; and,

3. It appealed to the specific need for counter-inflationary credibility implied by orthodox economic theories of macroeconomic policy-making.

\section{New Labour’s ‘New Times’}

The economy is becoming ever more global. Trade is growing at twice the speed of production. British Airways does its backroom work in Bombay, while a baker in South Yorkshire is taking on fifty new staff because his baguettes are selling so well in France. Yesterday's solutions will not work for tomorrow (Cook 1997).

Much of the literature that attempts to problematise the conventional wisdom on globalisation does so by presenting a series of empirical indicators that point to processes of structural economic change that fall well short of a genuinely global reality. Such indicators show fairly unequivocally that, however pervasive and superficially attractive, claims for globalisation are extremely difficult to substantiate in strict empirical terms. What is more, recent research has demonstrated that, for the British and other Northern European economies, external trading relations since the 1960s reveal a consistent pattern not of globalisation but of de-globalisation. Thus, for instance, the UK's share of intra-EU to extra-EU export trade has been inverted 
since 1960: from a ratio of 40:60 to one of 60:40 (Hay 2001b). However, to engage with the empirical arguments and nothing else may well be to divert attention away from what is arguably the most salient aspect of the globalisation debate.

In the years immediately preceding the 1997 election, Labour's leaders clearly both spoke and acted as if the most extreme variant of the globalisation hypothesis were an accurate description of reality. This had very real effects. In this way, the mere appeal to the notion of globalisation and the constraints it is seen to imply has served to institutionalise many of the consequences the discourse would claim to describe. The rhetoric of globalisation was used, we contend, to identify a set of economic conditions profoundly antithetical to the post-war social compromise, just as they are now seen to entail a revision, dilution and 'modernisation' of the 'European social model' ${ }^{8}$ The result has been a recasting of the post-war welfare state has been re-cast as a 'competition state' (Cerny 1990, 1997) and, increasingly, as a model for the 'revitalisation' and 'modernisation' of the European social model more generally. In a somewhat paradoxical victory of rhetoric over reality, such a process is taken as further evidence of the constraints that globalisation is perceived to impose, thus serving to reinforce the political resonance of the initial articulation of globalising 'necessities'.

In this way, the contingent logic of social and economic reform with which New Labour has come to be associated is rendered necessary by the appeal to globalisation as an exogenous economic constraint (cf. Evans 1997). This establishes parameters limiting the scope of future political decision-making in at least two ways. First, it serves to depoliticise contingent political choices (Burnham 2001). Second, the path dependent effects of such a process may serve, over time, to entrench and institutionalise a set of outcomes which were once merely contingent. Here the neoinstitutionalists are surely right. Paths, once established, may be difficult to retrace.

\footnotetext{
8 This has been described to us as the clear agenda of the British Government at the Lisbon Special European Council of March 2000 (interviews conducted by the authors, 10 Downing Street and the Cabinet Office).
} 
Such is the frequency with which exogenous processes of economic change have been appealed to as a guide for domestic policy that it is possible that the conventional wisdom of globalisation has itself become a conditioning influence on policy (Hay, Watson and Wincott 1999; Watson 2001). If true, it is important that one acknowledges that ideas about globalisation may have an independent causal impact on political outcomes over and above that which can be attributed to recent processes of structural economic change per se. That the Labour Party has chosen to deploy the rhetoric of globalisation is undeniable. It is crucial, then, that we establish on what terms it has done so.

The dominant suggestion, rhetorically, is one of a qualitative break with the past. The economic logic of the latest phase of capitalist development is assumed by the Labour Party to mark a clear transition with the post-war years. Moreover, as this logic has diffused and penetrated political structures, it is further assumed to have swept away the sedimented institutions and dominant conventions of a now bygone era. Even the now familiar addition of the prefix 'new' to the party's name - emphasised in Blair's first statement as Prime Minister, "We have been elected as New Labour; and we will govern as New Labour” (Blair 1997b) — is testament to such an assumption. The implicit suggestion is that we have witnessed a paradigm shift in the organisation of economic relations, requiring a similarly dramatic shift in the politics of economic regulation. "In a global economy,” Tony Blair argued in a speech to the Singapore Business Community, “the old ways won’t do ... In a modern economy, we [do not] need old style dirigisme” (1997a). Similarly, Gordon Brown argued at the final CBI Annual Conference before the 1997 General Election, "we understand that in a global market place, traditional national economic policies - corporatism from the old left — no longer have any relevance” (1996). As such,

The key to new Labour economics is the recognition that Britain .. [has] .. to compete in an increasingly international market place ... Today's Labour Party, new Labour, is the political embodiment of the changed world — the new challenges, the new policies and the new politics (Blair 1996a).

However else the Labour Party would subsequently present itself in the period 19951997, the first image which it wished to convey was that it should be seen as being 
qualitatively distinct from its former self. The novelty of 'New' Labour was juxtaposed to 'Old' Labour, just as the supposedly unique attributes of globalisation were emphasised in order to differentiate the logic of the current phase of capitalist development from the logic of capitalism per se.

In such a characterisation, causation runs unequivocally from the economic to the political. It is political actors that have had to 'respond' to the 'challenges' posed by the 'new realities' of changed economic circumstance. In this respect, Blair's warning to party supporters with reservations about the pace of Labour's political transformation "to stop living in the past and move with the times” is typical (1996b). So too his similarly phrased assessment of Lionel Jospin's hopes, expressed at the Congress of Socialist Parties in Malmo in June 1997, for a more aggressive and interventionist European stance on unemployment (1997c). The 'new times' of which Labour's leaders spoke were primarily new economic times; a residual economic determinism characterising the Party’s accounts of its own 'modernisation'.

It was through this implicitly determinist conception of the relationship between the economic and political spheres that much of the Party's new rhetoric on 'the market' was activated. The new structure of the international economy was seen to constrain, in particular, those parties most traditionally associated with the ethos of active economic government. ${ }^{9}$ Market-conforming policies were held increasingly to be 'enforced' by external economic pressures. In the 'business school' account of globalisation this logic is forcibly asserted - global economic processes sound the death knell for social democracy (Gray 1997). However, mindful perhaps of (further) alienating core constituencies, Labour's expression of an ultimately similar prognosis was more moderate in tone. "In the complex and increasingly integrated world economy,” Gordon Brown told the Party's influential Finance and Industry Group, "we need a clear appreciation of the role — and the limits — of government" (1995,

9 Activism is, of course, by no means wholly absent from New Labour's discursive repertoire. However, the much vaunted 'activation' of labour-market and social policy is in fact highly conditional. With respect to such arenas of intervention, the government is active only in translating perceived economic necessities into social imperatives. New Labour's activism is thus restricted to the active subordination of social policy to perceived economic exigencies (see also Levitas 1998; Lister 2002). 
emphasis added). Interestingly, this conception of the essential fallibility of government was introduced as an immediate precursor to the section of the speech headed, “No return to past failures”. In contrast to the 'failed' world of 'Old’ Labour, the 'future' world of 'New' Labour was one in which there would be no place for an over-active government. The rhetorical authority conveyed by this dualistic counterposing of old and new, failure and future, served to legitimate what was to become something of a New Labour mantra with respect to macroeconomic policy good government is minimal government.

The origins of such a view clearly lie in the business school globalisation literature. The world has experienced a systematic transfer of political power from states to markets; the space for alternatives to market-conforming agendas is, consequently, severely circumscribed. This theme has been tirelessly reiterated since the mid 1990s. Labour's globalisation rhetoric was predicated upon the assumption that exogenous economic forces ensured that "choices are constrained" in line with a strict macroeconomic orthodoxy. Above all else, Party officials saw globalisation as the end for the familiar “panaceas” of the 'old' left (Blair 1996a).

This assumption was deployed, with some degree of success, to disorient the natural political grammar associating market-conforming policies with the 'right', marketadjusting reforms with the 'left'. Blair, in particular, rejected the suggestion of an ideological betrayal. Market advocacy, he argued, was not so much an ideological choice as a technical necessity in an era of heightened capital mobility. A concerted effort was made to ensure that 'the market' might come to be identified as a legitimate symbol of the Party's political aspirations. It is within the context of this attempt to appropriate the traditional political economy of the British right (Thompson 1990) that we should understand Blair's insistence that, in the future, it will be common for “solutions adopted by left and right [to] overlap” (1996a). Blair's most direct enunciation of this theme came in a speech to the Lord Mayor's Banquet, six months after entering Downing Street. He chose this occasion to set out his definition of 'New' Labour, arguing in distinctly Giddensian terms for: 
a politics no longer scarred by the irrelevant ideological battles of much of the twentieth century... [M]ost of the left/right tags today are nothing but obstacles to good thinking (1997d).

Moreover, such was the rhetorical significance of globalisation that even this statement of basic political philosophy was set within the context of the technical requirements summoned by exogenous economic change. The internalisation of such imperatives and the consequent downsizing of Labour's aspirations for government marked a re-positioning in relation to 'the market' more pronounced than at any time during the modernisation process (Gamble 1996). Its early re-positioning under Kinnock and Smith had shifted the Party from a stance of outright hostility towards market principles to one of general scepticism towards market outcomes. From there, it progressed first to grudging acceptance, and finally to open embrace. Arguably, it is this that has made possible the exploration of the public/private boundary within the public sector which seems set to characterise Labour's second term.

“Modern government has a strategic role,” the Labour Party declared in its 1992 election manifesto, "not to replace the market but to ensure the market works properly” (1992: 11). This is a theme that key Party strategists picked up on and refined in the years following the 1992 electoral defeat. By 1996, Blair was willing to endorse only the first element of this statement. Whilst maintaining the view that "the modern function of government is not to second-guess the market” (1996a), the previous qualification that market-correcting interventions would still be sanctioned was now conspicuous only by its absence.

By 1997, the move away from discretionary policy-making, a move that has dominated the last twenty-five years of orthodox economic theory and Labour thinking alike, was confirmed. Labour now came to endorse a very different theory. This suggested that the limit of acceptable government intervention was the implementation of a rules-based policy. ${ }^{10}$ Within this emergent paradigm, the limits of a rational administration's economic activism are in supplying the market with

\footnotetext{
10 On the 'rules versus discretion' debate, see Drazen (2000). For a rather more political reading of that debate, see Burnham (1999).
} 
information about its intentions. This it does by publicising a series of medium-term macroeconomic targets.

One of the most notable aspects of Labour's new economic policy was the degree to which it conformed to the dictates of orthodox macroeconomic theory. In its desire to foster market expectations that it had created, in Gordon Brown's words, “a credible framework for monetary discipline” (1995), Labour elevated the perceived need to "set an explicit target for low inflation" to the "first goal of policy" (Blair 1996a). The suppression of inflationary tendencies was in turn assumed to entail a commitment to "lay down rules" which might establish a regime "fierce in controlling public spending” (Brown 1996). To this end, Brown published explicit spending targets, first as Shadow Chancellor and subsequently from the Treasury, in order that "nobody should doubt [his] iron resolve for stability and fiscal prudence" (press release, 28 April 1997). The theme was forcefully reiterated in Brown's Mansion House speech immediately following the party’s 2001 electoral triumph (2001).

As this suggests, the rhetoric of globalisation has consistently been deployed to explain the systemic shift in macroeconomic focus from employment-promoting to anti-inflationary preferences. As Blair suggested, in the new economic environment (although not necessarily before), "low inflation is not simply a goal in itself, it is the essential prerequisite both of ensuring that business can invest and that supply-side measures can work to raise the capacity of the economy to grow" (1995). Those operating within global foreign exchange markets are now assumed to be able to exert a considerable influence over the policy autonomy of governments who do not appear to share their concerns for price stability. The image cultivated by Labour's Treasury team in opposition - and later in government — was one of "more choice and freedom than ever before" for investors to move their financial assets where, when and how they pleased. In Brown’s words, “day to day flows of capital are greater and faster than ever before”. Consequently, "today, the judgement of the markets whether to punish or to reward government policies - is as swift as it is powerful” (cited in Shaw 1997).

This rapprochement with 'the market' would appear to be a reaction, specifically, to assumptions about global market relations. Perceptions of the necessity of market- 
conforming policies consistent with the 'business school' globalisation thesis were themselves presented as a logical consequence of the need to adopt counterinflationary policies consistent with the conclusions of orthodox macroeconomic theory.

Viewed in this way, any outward diffidence towards 'the market' — or, more accurately, towards the concerns for price stability of those operating within foreign exchange markets - is thought to force financial activity offshore. For assets to be retained within domestic markets any future Labour Government would have to “convince the markets” of its anti-inflationary credibility (Blair 1997b). A dual strategy was consequently adopted. On entering office, Blair's Government acted tough by reconfiguring the institutional environment in which British monetary policy was determined, in the hope of embedding a strict institutional 'logic' of counterinflationary credibility. Yet prior to that decision, and whilst still in opposition, Labour talked tough, sending the 'correct' counter-inflationary signals to those guardians of national liquidity, the international financial markets. Here the clear supposition was that speculative flows of short-term financial assets are triggered increasingly by expectations of future government policy, rather than by policy itself (Watson 1999b). To a significant extent, then, the 'demands' of a global era have been interpreted to imply that the execution of a 'successful' macroeconomic policy relies upon the execution of a 'successful' (i.e., credible) discursive strategy. Arguably macroeconomic policy here enters the realm of symbolic politics.

Of course, one way in which governments can increase the credibility of their economic discourse is to provide an institutional context which selects for - or, better still, guarantees - the policy outcomes embedded within that discourse. This the Blair Government achieved within a week of taking office by delegating operational control for the setting of interest rates to the Bank of England. By placing the key instrument of contemporary monetary policy beyond the direct control of the Treasury, Labour effectively externalised responsibility for counter-inflationary credibility (Balls 1998; Burnham 2001; Coates and Hay 2001). Such a deliberate attempt to depoliticise domestic monetary policy relations was guided by the assumption that "the City ... believes that the Bank will be a lot less tolerant about inflation than any government could be” (Daily Telegraph, 7 May 1997). This 
impression was almost immediately confirmed. For, the day after the reforms were announced, the British press reported genuine delight within the City of London at the Government's decision. Two comments from that day's Financial Times are sufficient to illustrate this point. John Sheppard, then chief economist at the ill-fated Japanese securities house, Yamaichi International, observed that "the government's credibility has been vastly improved by this bold step”. Similarly, Andrew Roberts, bond analyst at the Swiss Bank, UBS, remarked, "it is unbelievable to gain so much financial market credibility with such a simple move” (Financial Times, 7 May 1997).

Although the Government must have been tempted to emphasise the enhanced credibility that it had immediately generated for itself, its chosen rationalisation for this radical and unpredicted move (for which, arguably, it lacked a mandate) was rather different. Operational independence for the Bank of England was, it insisted, a necessary condition of competitiveness within the global economy. ${ }^{11}$ A clear distinction can thus be drawn between the way in which Labour presented the constraints of the international economic environment before it chose to grant operational independence to the Bank of England, and the way in which it rationalised that decision after the fact. The prior rhetorical stance suggests that the decision to cede interest rate control was driven by concerns to appear hyper-sensitive to inflationary pressures, in much the way implied by orthodox economic theories of macroeconomic policy-making. By contrast, the stance it later came to adopt was more expressive of concerns for internalising the interests of domestic capital - a stance more consistent with the structural dependence thesis.

National competitiveness has increasingly become a central preoccupation of governance strategies throughout the world (see Krugman 1994). What is clear from the British case is the way in which Labour appropriated such concerns as a means of providing its globalisation discourse with a popular political resonance. Had it constructed the challenges of globalisation merely in terms of the need to placate international financial markets, it left itself open to the charge that it had placed the

\footnotetext{
11 Here see, especially, Gordon Brown's letter to the Governor of the Bank of England, Eddie George, explaining the decision to reconfigure the institutional setting for interest rate policy. A full transcription appears in Financial Times, 07 May.
} 
interests of faceless overseas investors above those of British firms and, by extension, ordinary British people. By translating such imperatives into the language of competitiveness it could claim to answer to a more inclusive conception of the national interest and, in so doing, to offer a genuinely non-partisan economic policy.

Yet, in satisfying the need for domestic legitimation, Labour injected a number of contradictions into its economic message. On the one hand, it wished to be seen to advocate an avowedly non-interventionist economic policy, so that it would be apparent that it was "work[ing] with the grain of global change" to "embrace the global market” (Blair 1997b). At the same time, the task of promoting national competitiveness was clearly impossible in the absence of (market-correcting) political interventions. Loud and gratuitous proclamations of the essential limits of government were therefore translated rather unevenly into practice. There is, of course, no need for resonant discursive constructions to be internally coherent. Yet, the fact that Labour has so rarely been challenged to justify its globalisation discourse has allowed such contradictions to pass largely unnoticed.

Labour's stance on the issue of intervention has been to limit what might be seen as market-correcting measures to those "aimed at increasing the competitiveness of British companies in increasingly competitive markets” (Labour Industry Forum 1996: 2; see also Coates and Hay 2001). Here the clumsy repetition of the word 'competitive' serves as an index of the perceived significance of the concept. In this respect, there was little difference between Labour's aims and those of the previous Conservative Government - to generate "the right climate ... to help business to help itself” (DTI 1996: 1). The basis of this perhaps unlikely consensus was the desire to foster an economic climate that might be looked upon favourably by the managers of national and international capital alike. The relatively uncontested nature of national competitiveness strategies appeared to offer superficial evidence that investors were now able, at will, to confirm the state's structural dependence on capital through threats of disinvestment.

In order to stave off such threats, Labour has attempted to forward a competitiveness strategy that would translate macroeconomic precepts into microeconomic imperatives. It has consistently argued that its commitment to the interests of British 
capital is demonstrated at the macroeconomic level by its "determination to create a modern monetary framework" capable of "command[ing] confidence and credibility" (Brown, interview, Financial Times, 7 May 1997). Such a "stable low inflation environment" was presented as the "platform ... from which we can build our industrial strength” (1995). Yet it is through strategic microeconomic interventions that such 'industrial strength' is expected to emerge. In practice this has meant that — 'limits of government' rhetoric notwithstanding — it has imposed itself forcibly on the microeconomics of the labour market.

Labour's practice stands in some tension to the exaggerated claims of state obsolescence to be found in the 'business school' globalisation thesis. The state has not so much withered away due to external forces. Rather, its form and function have been subjected to wholesale redefinition through internal pressure (Jessop 1994; Watson 1999a). Labour's overall economic discourse has undergone a significant shift that reflects prior processes of internal state reform. Where once it had advocated an active state at the macroeconomic level, by 1997 it was content to make the case for a state whose economic competencies were restricted to the ability to intervene in line with perceived microeconomic imperatives. This represents a shift in both the form and content of state interventions from classical stabilisation policy (on the economics of which, see Stevenson, Muscatelli and Gregory 1988) to competitiveness enhancing strategies (on the politics of which, see Cerny 1997).

In this respect, Labour contested both the 1997 and 2001 General Elections with a conception of industrial policy narrower than at any time in the Party's history. Indeed, its industrial policy extended little further than a simple re-statement of its labour market policy. In the words of the 'Road to the Manifesto' documents, under a New Labour government:

What there will be is a new deal for people at work ... [The] world is changing ... Companies need both the capability and the flexibility to succeed in this new world ... We must avoid rigidity in labour market regulation and promote the flexibility we require (Labour Party 1996: 1). 
Similarly, when entering the debate on global economics from his position at the Foreign and Commonwealth Office, Robin Cook did so on almost identical terms:

Britain is a global player ... Companies must be able to adapt to a fast-changing market. Otherwise, they stop being competitive and cannot create jobs ... We must guarantee [that government legislation does not] over-burden business and destroy jobs (Cook 1997).

The deployment of a globalisation rhetoric consistent with the claims of structural dependence theorists therefore shifts the focus from a universal experience of globalising tendencies (what can be done now that no-one has the option to use discretionary macroeconomic policies?) to a much more particular experience (what can 'we' do to ensure that 'our' businesses are more competitive than their overseas rivals?). The discourse of globalisation constructed in the years immediately preceding the 1997 election is a flexible synthesis of quite distinct elements. The moral force with which Labour's leaders were able to articulate that discourse, and the political gains they were able to make by claiming for the Party the authoritative voice in negotiating the constraints of globalisation, owed much to the way that these very different elements were called upon to advance a single political programme of reform.

In the final concluding section, we consider Labour's success in harnessing the image of global economic 'forces' to mobilise widespread support for the political project to which it was already committed. The essence of Labour's success should be understood, as the title of this article implies, in terms of the Party's ability to render the contingent politics of orthodox macroeconomic management increasingly 'necessary' through appeal to the supposedly pervasive influence of external economic dynamics.

\section{Rendering the 'Necessary' Contingent Once Again: Contesting the Political Logic of No Alternative}


[T] he truth effects of discourses of economic globalisation are somewhat independent of the veracity of the analysis (Rose 1996: 354).

The popular and academic receptions of the discourse of globalisation on which Labour has drawn could not be more different. That this is so reflects the degree of critical scrutiny to which they have been exposed. The image of global economic change to which the Party appealed tended to be accepted uncritically by the British media. The academic response, however, has been altogether different. At exactly the time that Labour's leaders were seeking to popularise a 'strong' version of the globalisation thesis, such a thesis was exposed to intense and, we would suggest, devastating empirical critique (see, for instance, Berger and Dore 1996; Boyer and Drache 1996; Hirst and Thompson 1999). As the debate about globalisation consequently polarised around the two discordant camps of 'radicals' and 'sceptics' (on which, see Giddens 1999), little attention was paid to Labour's distinctive, eclectic and contradictory globalisation discourse. Such an analysis is long overdue.

New Labour's globalisation discourse, as we have sought to demonstrate, is complex, drawing on three distinct elements. Yet each of these reinforces a common political conclusion. Whilst, then, the Party's globalisation discourse was a flexible synthesis of ideas drawn from different — and often mutually incompatible — intellectual traditions, the separate elements of that discourse were forged together in a single political message.

1. By accepting the 'business school' globalisation thesis, Labour's leaders appropriated the image of a structurally weakened state necessarily ceding economic power to market imperatives. For twenty years, 'market exchange' had been synonymous with middle-class interests, especially for those elements of the middle-classes employed within the private sector. Labour now invoked the imperatives of globalisation to suggest that no government could resist an institutionalised system of 'market exchange'. By reiterating the theme of a structurally weakened state, Labour was able to relay a (convenient) political message directly to core marginals of 'middle England'. In adopting the language of the 'business school' 
thesis, it was tacitly admitting that it was now impossible to disentangle middle-class interests from the state policy-making agenda.

2. By accepting the theory of the state's structural dependence on capital, Labour's leaders highlighted the dangers that were posed by a system of enhanced exit options for any government that failed to convince the business lobby that it had internalised the preferences of capital. It presented globalisation as a regime of heightened capital mobility. In such an environment, businesses dissatisfied with government policy would relocate their production activities elsewhere, taking valuable sources of investment and jobs with them as they went. This allowed Labour to address the specific concerns of its new target constituencies with its reputation as a party of 'tax-and-spend'. Again by reiterating (in the face of strong empirical evidence to the contrary) a belief that, in a world of unbounded locational choice, businesses would refuse to invest in highlytaxed environments, Labour was able to reduce the tax agenda to a purely technical issue of 'competent' economic management in an era of globalisation.

3. By accepting orthodox theories of macroeconomic policy-making, Labour's leaders were able to withstand the charge that its depoliticisation of the economic agenda was merely an electoral ruse which would be reversed as soon as the Party took office. Investors operating within international financial markets, they claimed, would only tolerate policymakers with the reputation for counter-inflationary 'credibility'. Moreover, such a reputation would only be granted to those who tied their own hands in relation to future macroeconomic policy. By stating that a future Labour Government would pre-commit its policies into the longterm — and by institutionalising that pre-commitment in office - it was able to disarm anxieties that pre-election commitments would be sacrificed, at some point in the future, on the altar of a more progressive policy stance. The articulation of orthodox economic theories of macroeconomic policy-making therefore became a means of providing a market-friendly 'automatic pilot' for future policy. 
Through its success in combining these three narratives of external economic compulsion into a single political message, Labour was able to render its own preelection commitments ‘credible'. The language of 'necessity' which it invoked was a crucial element in such a process.

Yet it is only in one very limited sense that there is a necessitarian logic to New Labour's political economy. Having identified a new set of target constituencies with a (supposedly) natural aversion to more traditional economic policies, the need to construct a more orthodox policy stance became a condition of electoral rejuvenation. Having identified globalisation as an external constraint capable of enforcing convergence around orthodox policy norms, it was important that it was able to ascribe a logic of 'necessity' to globalisation. Such a necessitarian logic is then contingent only on the psephologically-conservative prior decision in 1997 and, indeed, 2001, to base the Party's electoral strategy on the appeal to the median voter in 'middle-England' marginals. In sum, then, we suggest, it was Labour's perceived electoral expediency which drove it to adopt a necessitarian discourse of globalisation rather than the converse.

We thus depart from the vast majority of the literature (both orthodox and heterodox), which accepts at face value New Labour's assessment that the external reality of globalisation shaped its 1997 General Election strategy and its conduct to date in office. Rather, we argue that it was the choice of electoral strategy which shaped the distinctive features of Labour's globalisation discourse. If we are to accept that the choice of any electoral strategy is a contingent and political decision, then we must conclude that the choice of one amongst many possible discourses of globalisation is also contingent and political. That the contingent politics of labour market and welfare reform has seemingly been rendered necessary is a triumph, not of the nonnegotiable character of globalisation, but of political rhetoric and electoral expediency over economic reality. 


\section{Bibliography}

Balls, E. (1998) 'Open Macroeconomics in an Open Economy: Scottish Economic Society/Royal Bank of Scotland Annual Lecture, 1997’, Scottish Journal of Political Economy, 45 (2), 113-32.

Barnet, R. and J. Cavanagh, J. (1994) Global Reach: The Power of the Multinational Corporations. New York: Simon and Schuster.

Berger, S. and Dore, R. (eds.) (1996) National Diversity and Global Capitalism. Ithaca, NY: Cornell University Press.

Blair, T. (1995) Mais Lecture, London, 22 May.

. (1996a) Speech to the Bundesverband der Deutschen Industrie e.V. Annual Conference, Bonn, 18 June.

—_. (1996b) Interview, Sunday Times, 1 September.

. (1997a) Speech to Labour Party workers, Royal Festival Hall, London, 2 May.

. (1997b) Speech to the Singapore Business Community, Singapore, 8 January.

. (1997c) Speech to the Congress of Socialist Parties, Malmö, 6 June.

. (1997d) Speech to the Lord Mayor’s Banquet, Guildhall, London, 10 November.

Boyer, R. and Drache, D. (eds.) (1996) States Against Markets: The Limits of Globalisation. London: Routledge.

Brown, G. (1995) Speech to the Labour Party Finance and Industry Group, 17 May.

. (1996) Speech to the Confederation of British Industry Annual Conference, Harrogate, 11 November.

. (2001) Speech at the Mansion House, London, 20 June.

Burnham, P. (1999) 'The Politics of Economic Management in the 1990s', New Political Economy 4 (1), 37-54.

—. (2001) 'New Labour and the Politics of Depoliticisation', British Journal of Politics and International Relations, 3 (2), 127-49.

Cerny, P. G. (1990) The Changing Architecture of Politics. London: Sage.

. (1997) 'Paradoxes of the Competition State: The Dynamics of Political Globalisation', Government and Opposition, 32, 251-74.

Clift, B. (2001) 'New Labour's Third Way and European Social Democracy', in S. Ludlam and M. J. Smith (eds.) New Labour in Government. Basingstoke: Macmillan.

Coates, D. and Hay, C. (2001) 'The Internal and External Face of New Labour's Political Economy', Government and Opposition, 36, forthcoming.

Cook, R. (1997) Speech to the Institute of European Affairs, Dublin, 3 November.

Department of Trade and Industry (1996) Competitiveness: Forging Ahead, Cm 2867. London: HMSO.

Drazen, A. (2000) Political Economy in Macroeconomics. Princeton, New Jersey: Princeton University Press.

Evans, P. (1997) 'The Eclipse of the State? Reflections on Stateness in an Era of Globalisation', World Politic, 50 (1), 62-87. 
Gamble, A. 'The Legacy of Thatcherism', in M. Perryman (ed.) The Blair Agenda. London: Lawrence and Wishart.

Garrett, G. (1995) 'Capital Mobility, Trade and the Domestic Politics of Economic Policy', International Organization, 49 (4), 657-87.

Giddens, A. (1998) The Third Way: The Renewal of Social Democracy. Cambridge: Polity.

. (1999) Runaway World. London: Profile Books.

. (2000) The Third Way and its Critics. Cambridge: Polity.

. (ed.) (2001) The Global Third Way Debate. Cambridge: Polity.

Gray, J. (1997) 'After Social Democracy: Politics, Capitalism and the Common Life’, in Endgames.

Cambridge: Polity.

. (1998) False Dawn: The Delusions of Global Capitalism. London: Granta.

Hay, C. (1997) 'Anticipating Accommodations, Accommodating Anticipations: The Appeasement of Capital in the Modernisation of the British Labour Party, 1987-1992', Politics and Society, 25, 234-56.

(1999) The Political Economy of New Labour: Labouring Under False Pretences?

Manchester: Manchester University Press.

. (2001a) 'Globalisation, Economic Change and the Welfare State: The Vexatious Inquisition of

Taxation?', in R. Sykes, B. Palier and P. M. Prior (eds.) Globalisation and European Welfare

States: Challenges and Change. Basingstoke: Palgrave.

— . (2001b) 'Globalisation, Competitiveness and the Future of the Welfare State in Europe', Paper presented at the conference of the European Community Studies Association, Madison, Wisconsin.

Hay, C. and Rosamond, B. (2002) 'Globalisation, European Integration and the Discursive Construction of Economic Imperatives’, Journal of European Public Policy, forthcoming.

Hay, C., Watson. M., and Wincott, D. (1999) Globalisation, European Integration and the Persistence of European Social Models, ESRC One Europe or Several?’ Working Papers, no. 3/99.

Hodgson, G. (1988) Economics and Institutions: A Manifesto for a Modern Institutional Economics. Cambridge: Polity Press.

International Monetary Fund (1997) Globalisation: Opportunities and Challenges, Special Issue of World Economic Outlook. New York: IMF.

Jessop, B. (1990) State Theory: Putting the Capitalist State in its Place. Cambridge: Polity Press.

. (1994) 'Changing Forms and Functions of the State in an Era of Globalisation and Regionalisation' in R. Delorme and K. Dopfer (eds) The Political Economy of Diversity: Evolutionary Perspectives on Economic Order and Disorder. Aldershot: Edward Elgar.

Kleinknecht, A.and ter Wengel, J. (1998) ‘The Myth of Economic Globalisation', Cambridge Journal of Economics, 22 (4), 637-47

Krugman, P. (1994) ‘Competitiveness: A Dangerous Obsession?’, Foreign Affairs, March/April, 28-44. . (1995) 'Dutch Tulips and Emerging Markets’, Foreign Affairs, 74, 28-44.

Kydland, F. and Prescott, E. (1977) 'Rules Rather than Discretion: The Inconsistency of Optimal Plans', Journal of Political Economy, 85 (3), 473-90. 
Labour Industry Forum (1996) Winning for Britain. London: Labour Party.

Labour Party (1992) It's Time to Get Britain Working Again: 1992 General Election Manifesto. London: Labour Party.

- (1996) Building Prosperity - Flexibility Efficiency and Fairness at Work, Road to the Manifesto. London: Labour Party.

Levitas, R. (1998) The Inclusive Society? Social Exclusion and New Labour. Basingstoke: Macmillan.

Lister, R. (2002) 'Towards a New Welfare Settlement?', in C. Hay (ed.) British Politics Today. Cambridge: Polity.

Lovecy, J. (2001) 'New Labour and the 'Left that is Left' in Western Europe', in D. Coates and P. Lawler (eds.) New Labour in Power. Manchester: Manchester University Press.

McNabb, R. and McKenna, C. (1990) Inflation in Modern Economies. Hemel Hempstead: Harvester Wheatsheaf.

Ohmae, K. (1990) The Borderless World. London: Collins.

O’Neill, J. (1998) The Market: Ethics, Knowledge and Politics. London: Routledge.

Persson, T. and Tabellini, G. (1990) Macroeconomic Policy, Credibility and Politics. London: Harwood Academic Publishers.

Piven, F. P. (1995) 'Is It Global Economics or Neo-Laissez Faire?’, New Left Review 213, 107-14.

Przeworski, A. and Wallerstein, M. (1988) 'Structural Dependence of the State on Capital', American Political Science Review, 82 (2), 11-30.

Reich, R. (1992) The Work of Nations. New York:Vintage Books.

Rose, N. (1996) 'The Death of the Social? Re-Figuring the Territory of Government', Economy and Societ, 25, (3), 327-56.

Sachs, J. and Warner, A. (1995) 'Economic Reform and the Process of Global Integration', Brookings Papers on Economic Activity, no. 1, 1-118.

Shaw, E. (1997) 'The Trajectory of New Labour: Some Preliminary Thoughts', paper presented at the American Political Science Association, Washington, August 28-31.

Stevenson, A., Muscatelli, V. and Gregory, M. (1988) Macroeconomic Theory and Stabilisation Policy. London: Philip Allan.

Taylor, J. (1983) ‘Comment’, Journal of Monetary Economics, 12, (1), 123-5.

Thompson, G. (1990) The Political Economy of the New Right. London: Pinter.

Watson, M. (1999a) 'Globalisation and the Development of the British Political Economy', in David Marsh et al, Postwar British Politics in Perspective. Cambridge: Polity Press.

_- (1999b) 'Rethinking Capital Mobility, Reregulating Financial Markets', New Political Economy, 3 (3), 407-26.

. (2001) 'International Capital Mobility in an Era of Globalisation: Adding a Political Dimension to the "Feldstein-Horrioka Puzzle”, Politics, 21 (2), 81-92.

. (2002) 'The Institutional Paradoxes of Monetary Orthodoxy: Reflections on the Political Economy of Central Bank Independence', Review of International Political Economy, 9 (1), 183-96. 
Wickham-Jones, M. (1995) 'Anticipating Social Democracy, Pre-empting Anticipations: Economic Policy-Making in the British Labour Party, 1987-1992', Politics and Society, 23 (4), 465-94. . (1996) Economic Strategy and the Labour Party: Politics and Policy-Making, 1970-83. Basingstoke: Macmillan.

- (2000) 'New Labour and the Global Economy: Partisan Politics and the Social Democratic Model', British Journal of Politics and International Relations, 2 (1), 1-25. 